\title{
Platelet-activating factor induces the expression of early pregnancy factor activity in female mice*
}

\author{
C. Orozco, T. Perkins and F. M. Clarke \\ School of Science, Griffith University, Nathan, Queensland 4111, Australia
}

\begin{abstract}
Summary. When synthetic platelet-activating factor (PAF, 1-0-alkyl-2-acetyl-snglycero-3-phosphocholine) was injected into mature female mice during dioestrus, pro-oestrus or oestrus, it induced the expression of early pregnancy factor (EPF) activity in the sera of these animals within $1 \mathrm{~h}$ of injection. The sera of similarly injected males, metoestrous or immature females did not display any EPF activity. The results suggest that embryo-derived PAF may be the ovum factor responsible for triggering the generation of serum EPF activity during the preimplantation stages of pregnancy.
\end{abstract}

\section{Introduction}

It has been shown that mild thrombocytopenia is an initial maternal response to fertilization: in mice (O'Neill, 1985a) and women (O'Neill et al., 1985) the presence of a viable preimplantation embryo causes a reduction in the peripheral blood platelet count. Further experimentation (O'Neill, 1985a, b; O'Neill et al., 1985) has revealed that the zygote releases a factor which, when injected into splenectomized mice, causes thrombocytopenia. Analysis of this embryo-derived factor (O'Neill, 1985c) has shown that it possesses chemical, biochemical and physiological properties similar to those of the well characterized (Snyder, 1985) platelet-activating factor, PAF (1-0-alkyl-2-acetyl-sn-glycero-3-phosphocholine). The embryo-derived PAF is produced within hours of fertilization and its production persists throughout the peri-implantation period when it is probably responsible for the thrombocytopenia detected by peripheral blood platelet counts. As such it constitutes a very early embryonic signal causing alterations in maternal physiology.

The only other very early embryonic signal so far described is an 'ovum factor', which induces the generation of early pregnancy factor (EPF) activity in maternal serum during the periimplantation stage of pregnancy (Morton et al., 1980; Cavanagh et al., 1982). This EPF activity is detected in pregnancy sera by use of an assay called the rosette inhibition test (Morton et al., 1976). When lymphocytes are exposed to heterologous red blood cells in the presence of a complement source, a small sub-population of the lymphocytes binds red blood cells to form spontaneous rosettes. The formation of these rosettes may be inhibited in a dose-dependent manner by prior treatment of the lymphocytes with an anti-lymphocyte serum (ALS), and so for a given ALS a rosette inhibition titre may be defined (Bach \& Antonie, 1968; Morton et al., 1975). When lymphocytes have previously been incubated in pregnancy serum an increased rosette inhibition titre of the standard ALS used in the assay is observed and it is this increase in titre which has been defined as EPF activity (Morton et al., 1976; Clarke \& Wilson, 1982). Using this assay, EPF activity can be detected within hours of fertilization and persists in the maternal serum for at least the first two thirds of pregnancy (Morton et al., 1976, 1977, 1979, 1983; Smart et al., 1982; Koch et al., 1983). Extensive studies (Morton et al., 1980; Cavanagh et al., 1982) have shown that, in the periimplantation period, the generation of EPF activity requires the continued production of a signal

\footnotetext{
*Reprint requests to Dr F. M. Clarke.
} 
('ovum factor') from the zygote or embryo. After implantation EPF activity appears to be generated via the placenta (Morton, 1984).

O'Neill (1985c) has previously noted circumstantial evidence for similarities between 'ovum factor' and the embryo-derived PAF; for example, partial characterization of 'ovum factor' has shown it to be a low molecular weight molecule(s) with a strong tendency to associate with carrier proteins (Cavanagh et al., 1982). In these physical characteristics it is similar to PAF (Snyder, 1985). Given the temporal coincidence of the production of 'ovum factor' and embryo-derived PAF, we have examined whether there was any relationship between the two early embryonic signals.

\section{Materials and Methods}

\section{$P A F$}

Synthetic platelet activating factor (1-0-octadecyl-2-acetyl-sn-glycero-3-phosphocholine) was obtained from Boehringer (Mannhein, FRG): $10 \mathrm{mg}$ were dissolved in $2 \mathrm{ml}$ absolute ethanol and aliquants were stored at $-30^{\circ} \mathrm{C}$. For use in injection experiments, or for testing in the RIT dilutions of this stock were made in phosphate-buffered saline (PBS, $0.02 \mathrm{M}-\mathrm{NaP}_{\mathrm{i}} ; 0.09 \%(\mathrm{w} / \mathrm{v}) \mathrm{NaCl} \mathrm{pH} 7.4$ ) containing $0.25 \%$ bovine serum albumin (BSA fraction $V$ powder: Sigma Chemical $\mathrm{Co}$.).

\section{PAF-injected mice and collection of sera}

Female Quackenbush mice (6-8 weeks old) were screened (Rugh, 1968) by vaginal smears to determine the stage of the reproductive cycle and classified as being dioestrus, pro-oestrus, oestrus or metoestrus. These were then divided into test and control groups. The test groups were injected intra-peritoneally with $1 \mathrm{ng}$ PAF ( $100 \mu \mathrm{l}$ of $0.01 \mathrm{ng}$ PAF/ $\mu$ l PBS-BSA) while the control groups were injected i.p. with $100 \mu \mathrm{l}$ PBS-BSA. The mice were bled $1 \mathrm{~h}$ after the injection by cardiac puncture under ether anaesthesia. The blood was allowed to clot for $1 \mathrm{~h}$ at room temperature before centrifugation and collection of serum. The sera were inactivated by heating at $56^{\circ} \mathrm{C}$ for 30 min then stored at $-30^{\circ} \mathrm{C}$. Immature female mice (2-3 weeks) and mature male mice (6-8 weeks) were also allocated to test and control groups and injected, and serum was collected as described above.

\section{Collection of serum from pregnant mice}

Mature female Quackenbush mice (6-8 weeks) were placed with fertile males and checked each morning $(08: 30 \mathrm{~h})$ for the presence of vaginal plugs. Those with plugs were segregated and bled for serum collection at 2,5 or 10 days after mating.

\section{Rosette inhibition test}

The rosette inhibition test for the detection of EPF activity was based on the procedure described by Morton et al. (1976) and Rolfe et al. (1984). The procedure has been modified in this laboratory, greatly increasing the ease and consistency of the assay. These modifications are noted below.

Lymphocyte preparation. Spleen cell suspensions were prepared in Hanks' balanced salt solution (HBSS) from the spleens of mature male Quackenbush mice. The red blood cells were removed using the Tris/ $\mathrm{NH}_{4} \mathrm{Cl}$ lysis procedure (Ferreira, 1976) rather than the water lysis procedure recommended by Rolfe et al. (1984). We have found the Tris/ $\mathrm{NH}_{4} \mathrm{Cl}$ procedure to be more efficient and 
consistent in providing complete removal of red blood cells and a higher yield of lymphocytes. After two washes in HBSS, the lymphocyte suspension was adjusted to $15 \times 10^{6} \mathrm{cells} / \mathrm{ml}$.

Human red blood cells. Fresh human red blood cells (HRBC) were obtained daily from the same donor (3-drops by finger puncture into $10 \mathrm{ml}$ HBSS), washed 3 times and made to a final suspension of $10^{8}$ cells $/ \mathrm{ml}$.

Human serum. Human serum was used as a source of complement for rosette formation. Routinely, $15 \mathrm{ml}$ blood were collected by venepuncture from the same donor who provided the red blood cells for rosette formation. The blood was allowed to clot for 30-60 min at room temperature before centrifugation. The serum was collected and dispensed into tubes in $60 \mu 1$ aliquants and stored frozen at $-30^{\circ} \mathrm{C}$ until required. For use in the assay an aliquant was thawed and diluted 1 in 60 with HBSS immediately before use. Human serum has been found to be a far more convenient and effective source of complement than the guinea-pig serum used by Morton et al. (1976) and Rolfe et al. (1984). Because it was obtained from the same donor as the RBCs there was no need for the extensive absorptions required with guinea-pig serum (see Rolfe et al., 1984), and furthermore, it was more efficient at inducing rosette formation between mouse lymphocytes and human RBCs, working most effectively at a dilution of 1 in 60 compared to the 1 in 5 of guinea-pig serum (see Rolfe et al., 1984).

Sample incubation with lymphocyte preparation. The $1 \mathrm{ml}$ aliquants of the lymphocyte suspension were centrifuged at $400 \mathrm{~g}$ for $5 \mathrm{~min}$ and the supernatant was aspirated. The cell pellets were resuspended in $200 \mu \mathrm{l}$ of test sample diluted in PBS. The test samples were routinely tested over a range of dilutions as noted in the 'Results' section. After incubation at $37^{\circ} \mathrm{C}$ for $30 \mathrm{~min}$ the cells were sedimented and then washed twice in $2 \mathrm{ml}$ HBSS. After the final centrifugation the cells were resuspended in a final volume of $1 \mathrm{ml}$ HBSS, and dispensed into the antilymphocyte serum dilutions as described below.

ALS incubations. Rabbit anti-mouse lymphocyte serum (ALS), prepared as described by Morton et al. (1975), was diluted to 1 in $10^{6}$ with HBSS. This $10^{-6}$ dilution was then used to prepare 8 tubes containing $240 \mu$ l of the following dilutions of ALS: 1 in $10^{6}, 1$ in $4 \times 10^{6}, 1$ in $16 \times 10^{6}, 1$ in $64 \times 10^{6}, 1$ in $10^{9}, 1$ in $16 \times 10^{9}, 1$ in $256 \times 10^{9}, 1$ in $4 \times 10^{12}$. Two control tubes containing $240 \mu \mathrm{l} \mathrm{HBSS}$ were also included in each assay, giving a total of 10 tubes. Then $100 \mu \mathrm{l}$ lymphocyte suspension and $50 \mu \mathrm{l}$ of 1 in 60 diluted human serum (as a source of complement) were added to each of the tubes which were incubated at $37^{\circ} \mathrm{C}$ for $80 \mathrm{~min}$. The preparation of the ALS dilutions and the dispensing of lymphocytes and complement were all performed with a Hamilton-Microlab $\mathbf{M}$ diluter-dispenser which has an accuracy and reproducibility of $\pm 1 \%$.

Rosette formation and counting. After the $80 \mathrm{~min}$ incubation the tubes were removed from the incubator and placed on the bench. Then $100 \mu \mathrm{l}$ of a suspension of human RBCs (see above) were added to each of the tubes which were immediately centrifuged at $200 \mathrm{~g}$ for $5 \mathrm{~min}$. The pellets were gently resuspended by mixing end over end on a Matburn wheel for $5 \mathrm{~min}$. The suspensions were then spread on double-chamber, bright-line Neubauer haemocytometers and the number of rosettes in the entire field in both chambers was counted using a Visopan projection microscope.

The average number of rosettes in each of the $8 \mathrm{ALS}$ dilutions was recorded as a percentage of the mean number in the control tubes containing no ALS. The rosette inhibition titre (RIT) was recorded as the highest ALS dilution in which the number of rosettes formed was $<75 \%$ of the number formed in the control tubes in the absence of ALS. In the past, the RIT has been expressed as the $\log _{2}$ [reciprocal dilution of ALS $\left.\times 10^{-3}\right]$ (Rolfe et al., 1984) and this practice has been used in presenting the current results. Thus, if rosette formation is inhibited to an ALS dilution of 1 in $4 \times 10^{6}$, the RIT is expressed as 12 . Using this modified assay procedure a single operator can routinely achieve 16-20 assays per day. 


\section{Results}

Figures 1(a)-1(f) show typical assay results obtained after incubation of mouse lymphocytes with control (PBS) and test samples. The narrow error range and clearly defined inhibition titres attest to the consistency of the modified assay procedure. As illustrated in Fig. 1(a), when normal spleen cells had been preincubated in PBS, the RIT of the ALS was 12. The consistency of the assay was further confirmed by the fact that throughout the course of these studies 90 PBS control assays were performed. In all, 85 yielded an RIT of 12, the remaining 5 an RIT of 14 which gives a mean control RIT of $12 \cdot 11 \pm 0 \cdot 47$. In agreement with previous observations (Morton et al., 1976, 1979), preincubation of the lymphocytes with male sera (Fig. lb) or female sera (obtained at any stage of the cycle; results with serum from an oestrous female illustrated in Fig. 1c) did not result in any change in the RIT. On the other hand, as has been established by many previous studies (Morton $e t$

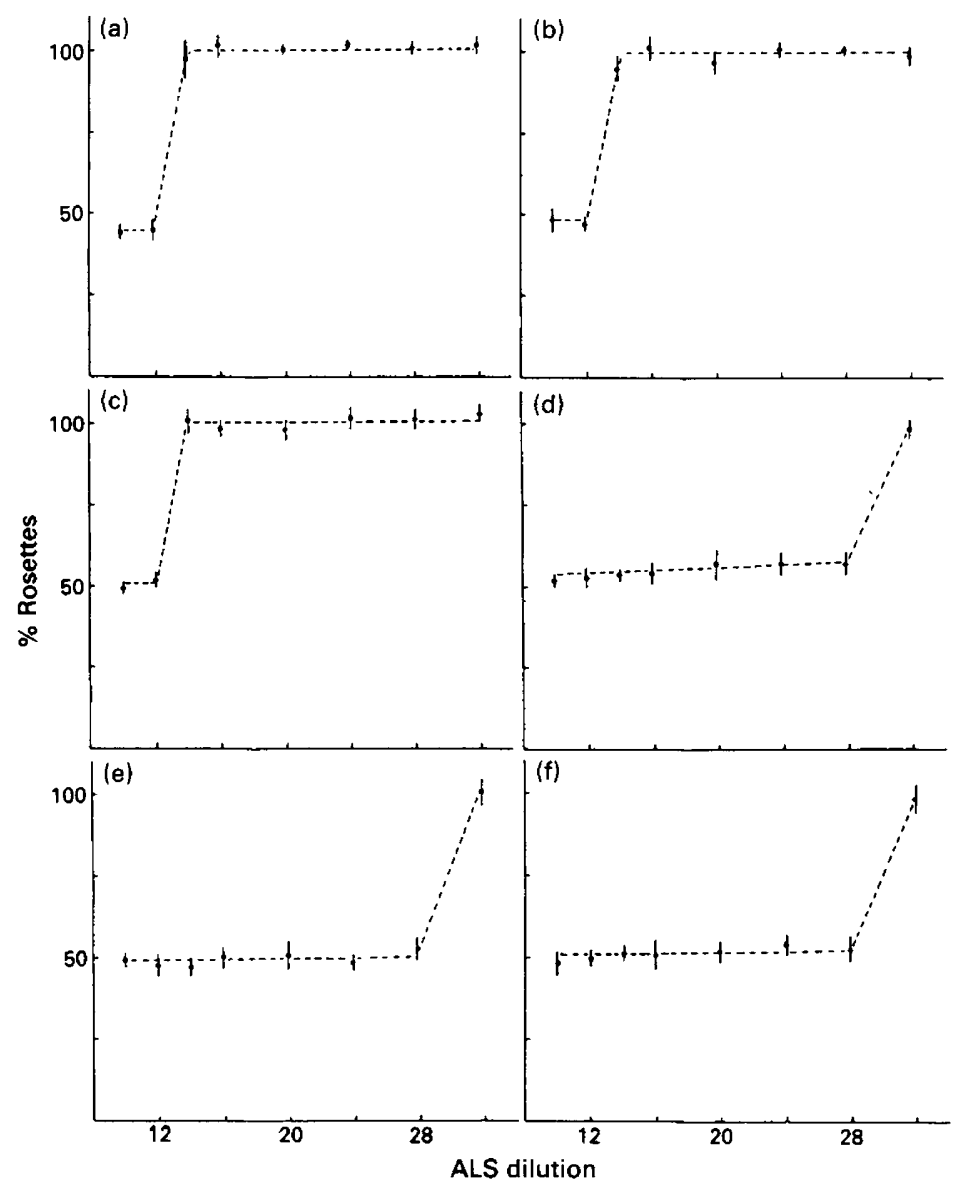

Fig. 1. Rosette inhibition assays obtained with the improved test procedure. Each figure shows rosette formation (as \% of control with no ALS) by normal lymphocytes as a function of ALS dilution (expressed as $\log$ (base 2 ) of reciprocal dilution $\times 10^{-3}$ ) after incubation of the lymphocytes in: (a) PBS; (b) male mouse serum; (c) serum from oestrous mouse; (d) serum from mouse at Day 2 of pregnancy; (e) serum from mouse at Day 5 of pregnancy; (f) serum of oestrous mouse after PAF injection. All sera were tested at a 1 in 40 dilution in PBS. Each point represents mean \pm s.d. of quadruplicate determinations obtained from 4 different assays on each sample on 4 different days using different lymphocyte preparations. 
al., 1976, 1977, 1979; Koch et al., 1983), preincubation of the lymphocytes in serum from pregnant mice (examples with 2- and 5-day sera are shown in Figs $1 \mathrm{~d}$ and le) resulted in a marked increase in the RIT to 28, indicating the presence of EPF activity in these samples. The increased rosette inhibition titres induced by preincubation with pregnancy sera were very well defined by the present assay (see Figs $1 \mathrm{~d}$ and $1 \mathrm{e}$, and $1 \mathrm{a}-\mathrm{c}$ ) and attest to the validity of this assay in the detection of EPF activity.

Table 1. Induction of serum EPF activity by PAF

\begin{tabular}{|c|c|c|c|c|}
\hline \multirow[b]{2}{*}{ Serum sample } & \multirow[b]{2}{*}{$\begin{array}{c}\text { No. of } \\
\text { mice }\end{array}$} & \multicolumn{2}{|c|}{ RIT* } & \multirow[b]{2}{*}{$\begin{array}{c}\text { EPF } \\
\text { activity } \dagger\end{array}$} \\
\hline & & $\begin{array}{c}1 / 8 \\
\text { Dilution }\end{array}$ & $\begin{array}{c}1 / 40 \\
\text { Dilution }\end{array}$ & \\
\hline \multicolumn{5}{|l|}{ Control females } \\
\hline Dioestrus & 3 & 12 & 12 & - \\
\hline Pro-oestrus & 3 & 12 & 12 & - \\
\hline Oestrus & 3 & 12 & 12 & - \\
\hline Metoestrus & 3 & 12 & 12 & - \\
\hline \multicolumn{5}{|c|}{$P A F$-injected females } \\
\hline Dioestrus & 4 & 28 & 28 & + \\
\hline Pro-oestrus & 4 & 28 & 28 & + \\
\hline Oestrus & 4 & 28 & 28 & + \\
\hline Metoestrus & 4 & 12 & 12 & - \\
\hline \multicolumn{5}{|l|}{ Males } \\
\hline Control & 4 & 12 & 12 & - \\
\hline PAF-injected & 4 & 12 & 12 & - \\
\hline \multicolumn{5}{|l|}{ Immature females } \\
\hline Control & 4 & 12 & 12 & - \\
\hline PAF-injected & 4 & 12 & 12 & - \\
\hline
\end{tabular}

To test for possible relationships between the EPF-inducing ovum factor (Cavanagh et al., 1982) and the embryo-derived PAF (O'Neill, 1985a, b; O'Neill et al., 1985), groups of male, female and immature female mice were injected with $1 \mathrm{ng}$ PAF in PBS-BSA or PBS-BSA alone. After $1 \mathrm{~h}$ they were bled, serum was collected and then assayed in the rosette inhibition test. The results of these studies are summarized in Table 1. In keeping with previous observations (Morton et al., $1976,1977,1979)$ none of the sera from the control groups, male or female, showed any evidence of EPF activity. When assayed over a 5-fold range of concentration these sera were uniformly negative, yielding RITs of 12, the same as the PBS controls. However, when PAF was injected into female mice at certain stages of the reproductive cycle, i.e. at dioestrus, pro-oestrus, or oestrus, the sera collected $1 \mathrm{~h}$ later displayed EPF activity, with increased RITs of 28 being consistently obtained (Table 1). An example of the repetitive, positive assay results obtained with one of these sera from a PAF-injected oestrous mouse is shown in Fig. 1(f). By way of contrast, PAF injection of the metoestrous or immature groups of females did not result in the expression of serum EPF activity (Table 1). Similarly, PAF-injected male mice did not display any serum EPF activity (Table 1). Similarly, PAF-injected male mice did not display any serum EPF activity (Table 1). PAF itself was not active when directly assayed in the rosette inhibition test. Lymphocytes preincubated with PAF over the range of $1 \mathrm{fg}$ to $100 \mathrm{ng}$ gave RITs of 12, exactly the same as lymphocytes incubated in the control PBS. 


\section{Discussion}

The results reveal that synthetic PAF can induce the expression of serum EPF activity when injected into mature female mice at all stages of the oestrous cycle except metoestrus. Cavanagh et al. (1982) have shown that injection of oestrous mice with culture fluid from fertilized eggs also results in the expression of serum EPF activity. This activity in ovum culture fluid has been ascribed (Cavanagh et al., 1982) to a partly characterized 'ovum factor'. This 'ovum factor' (like PAF) is not itself active in the rosette inhibition test; rather it is believed (Cavanagh et al., 1982; Morton, 1984) to act as a primary signal, inducing and interacting with secondary factors which act to generate the RIT-active EPF species from pre-existing inactive precursors (Clarke \& Wilson, 1985). O'Neill (1985a, b) and O'Neill et al. (1985) have shown that injection of the ovum culture fluid into mice also induces platelet activation and thrombocytopenia. Moreover, they have identified the active agent as a PAF-acether (analogous to the synthetic PAF used in these studies) and suggest that this embryo-derived PAF is responsible for the maternal thrombocytopenia observed during the peri-implantation phase of pregnancy.

The present studies indicate that, in all probability, the ovum factor responsible for the induction of EPF-activity in the peri-implantation stage of pregnancy is the same as the embryoderived PAF which is responsible for the altered maternal platelet physiology at this time. While further studies will be necessary to identify 'ovum factor' unequivocally as PAF, and to discover its mode of action in inducing expression of serum EPF activity, the present observations provide a link between the only two very early pregnancy phenomena, EPF and platelet activation, so far described.

This work was supported by grants from the National Health and Medical Research Council of Australia.

\section{References}

Bach, J.F. \& Antonie, B. (1968) In vitro detection of immunosuppressive activity of anti-lymphocyte sera. Nature, Lond. 217, 658-659.

Cavanagh, A.C., Morton, H., Rolfe, B.E. \& Gidley-Baird, A.A. (1982) Ovum factor: a first signal of pregnancy? Am. J. Reprod. Immunol. 2, 97-101.

Clarke, F.M. \& Wilson, S. (1982) Biochemistry of early pregnancy factor. In Pregnancy Proteins, pp. 407-412. Eds J. G. Grudzinskas, B. Teisner \& M. Seppala. Academic Press, Sydney.

Clarke, F.M. \& Wilson, S. (1985) In search of EPF. In Early Pregnancy Factors, pp. 165-177. Eds F. Ellendorff \& E. Koch. Perinatology Press, New York.

Ferreira, E. (1976) Reactions involving cytolytic antibody and normal lymphocytes. In Manual of Clinical Immunology, pp. 858-867. Eds N. E. Rose \& H. Friedman. Am. Soc. of Microbiology, Washington.

Koch, E., Morton, H. \& Ellendorfi, F. (1983) Early Pregnancy Factor: biology and practical application. $\mathrm{Br}$. vet. J. 139, 52-58.

Morton, H. (1984) Early pregnancy factor (EPF) a link between fertilization and immunomodulation. Aust. J. biol. Sci. 37, 393-407.

Morton, H., Hegh, V. \& Clunie, G.J.A. (1975) Antilymphocyte serum: studies of the rosette-inhibiting antibody in rabbit anti-mouse ALS. Aust. J. exp. Biol. med. Sci. 53, 373-380.

Morton, H., Hegh, V. \& Clunie, G.J.A. (1976) Studies of the rosette inhibition test in pregnant mice: evidence of immunosuppression? Proc. R. Soc. B 193, 413-419.

Morton, H., Rolfe, B., Clunie, G.J.A., Anderson, M.J. \& Morrison, J. (1977) An early pregnancy factor detected in human serum by the rosette inhibition test. Lancet i, $394-397$.

Morton, H., Nancarrow, C.D., Scaramuzzi, R.J., Evison, B.M. \& Clunie G.J.A. (1979) Detection of early pregnancy factor in sheep by the rosette inhibition test. $J$. Reprod. Fert. 56, 75-80.

Morton, H., Rolfe, B.E., McNiell, L., Clarke, F.M. \& Clunie, G.J.A. (1980) Early pregnancy factor: tissues involved in its production in the mouse. $J$. Reprod. Immunol. 2, 73-82.

Morton, H., Morton, D.J. \& Ellendorff, F. (1983) The appearance and characteristics of early pregnancy factor in the pig. J. Reprod. Fert. 68, 437-446.

O'Neill, C. (1985a) Thrombocytopenia is an initial maternal response to fertilization in mice. $J$. Reprod. Fert. 73, 559-566.

O'Neill, C. (1985b) Examination of the causes of early pregnancy-associated thrombocytopenia in mice. $J$. Reprod. Fert. 73, 567-577.

O'Neill, C. (1985c) Embryo derived platelet activating factor. In Early Pregnancy Factors, pp. 261-266. Eds F. Ellendorff \& E. Koch. Perinatology Press, New York.

O'Neill, C., Gidley-Baird, A.A., Pike, I.L., Porter, R.N., Sinosich, M.J. \& Saunders, D.M. (1985) Maternal 
blood platelet physiology and luteal-phase endocrinology as a means of monitoring pre- and postimplantation embryo viability following in vitro fertilization. J. in vitro Fert. Embryo Transfer, 2, 87-93.

Rolfe, B., Cavanagh, A., Forde, C., Bastin, F., Chen, C. \& Morton, H. (1984) Modified rosette inhibition test with mouse lymphocytes for detection of early pregnancy factor in human pregnancy serum. J. Immunol. Methods 70, 1-11.

Rugh, R. (1968) The Mouse, its Reproduction and Development, p. 45. Burgess Publishing Co. Minneapolis.
Smart, Y.C., Roberts, T.K., Frasser, I.S., Cripps, A.W. \& Clancy, R.L. (1982) Validation of the rosette inhibition test for the detection of early pregnancy in women. Fert. Steril. 37, 799-785.

Snyder, F. (1985) Chemical and biochemical aspects of platelet activating factor: a novel class of acetylated ether-linked choline-phospho-lipids. Med. Research Rev. 5, 107-140.

Received 3 March 1986 